\title{
STUDI KELAYAKAN PEMBENTUKAN BUMD ANEKA USAHA DI KABUPATEN SAMOSIR
}

\author{
Kornel Munthe \\ Universitas Katolik Santo Thomas Medan Jl. Setia Budi No. 479F, 20132, Indonesia \\ e-mail: kornel_munthe@yahoo.com
}

\begin{abstract}
The purpose of this study is to analyze the feasibility of establishing a Regional Owned Enterprise (BUMD) conducted by the Regional Government of Samosir Regency. The study was conducted in April-August 2018 with data collection techniques in the form of observation, interviews, and documentation. This study uses a quantitative method with three Investment Criteria, namely: Net Present Value (NPV), Net Benefit Cost Ratio (Net B / C), Internal Rate of Return (IRR); and Pay Back Period Analysis (PBP). Based on the results of finanasial analysis, NPV =49,771,120,662.86; Net B / $C=12.78 ; I R R=32 \%$, analysis of Pay Back Period for 4 years. Based on the results of the analysis it can be concluded that the planned establishment of various business enterprises in Samosir Regency is feasible.
\end{abstract}

Keywords: Business feasibility study, investment criteria.

\section{PENDAHULUAN}

Sesuai dengan Undang-Undang Nomor 23 Tahun 2014 tentang Pemerintahan Daerah telah memberikan hak, tugas dan tanggung jawab kepada Pemerintah Daerah untuk mengatur dan mengurus sendiri urusan pemerintahan menurut asas otonomi.Pemberian otonomi luas kepada daerah diarahkan untuk memperluas dan mempercepat terwujudnya peningkatan kesejahteraan masyarakat melalui peningkatan pelayanan, pemberdayaan dan peranserta masyarakat.Untuk melaksanakan otonomi daerah yang luas dan bertanggung jawab, setiap daerah memerlukan kewenangan dan kemampuan untuk menggali sumber daya yang ada di daerahnya masing-masing guna meningkatkan Pendapatan Asli Daerah dari tahun ke tahun.Penggalian sumber dana daerah tersebut diperlukan untuk menunjang keberhasilan pelaksanaan pembangunan maupun otonomi daerah. Pelaksanaan otonomi daerah secara luas, nyata, dan bertanggung jawab yang dilimpahkan pemerintah pusat kepada daerah menuntut pemerintah daerah membentuk badan yang mempunyai tugas untuk mengelola keuangan daerah dan kekayaan daerah.

Berdasarkan Pasal 285 Undang-Undang Nomor 23 Tahun 2014 tentang Pemerintahan Daerah dan Pasal 6 ayat (1) Undang-Undang Nomor 33 Tahun 2004 tentang sumber-sumber keuangan yang menjadi penerimaan pemerintah daerah yang terdiri atas Pendapatan Asli Daerah (PAD), Dana Perimbangan, dan Lain-lain Pedapatan yang Sah, diatur dalam UndangUndang Nomor 33 Tahun 2004 tentang Perimbangan Keuangan antara Pemerintah Pusat dan Daerah. Penerimaan pemerintah daerah tersebut merupakan sumber pendapatan yang sangat diperlukan guna terselenggaranya pemerintahan, pembangunan masyarakat, dan pelayanan publik. PAD bertujuan untuk memberikan keleluasaan kepada daerah dalam mengoptimalkan potensi pendanaan daerah sendiri dalam pelaksanaan otonomi daerah sebagai perwujudan asas desentralisasi. Diketahui besarnya Pendapatan Asli Daerah dapat menjadi salah satu indikator dalam menilai peran dan kemampuan daerah dalam membiayai pembangunan dan rumah tangganya sendiri (self-supporting). Oleh karena itu PAD memiliki posisi strategis dalam proses pelaksanaan pembangunan daerah, karena digunakan untuk membiayai sebagian belanja pembangunan setiap tahunnya.Adapun untukpersentase realisasi penerimaan menurut Jenis Penerimaan di Kabupaten Samosir Tahun 2012-2016 disajikan pada Gambar 1 berikut. 


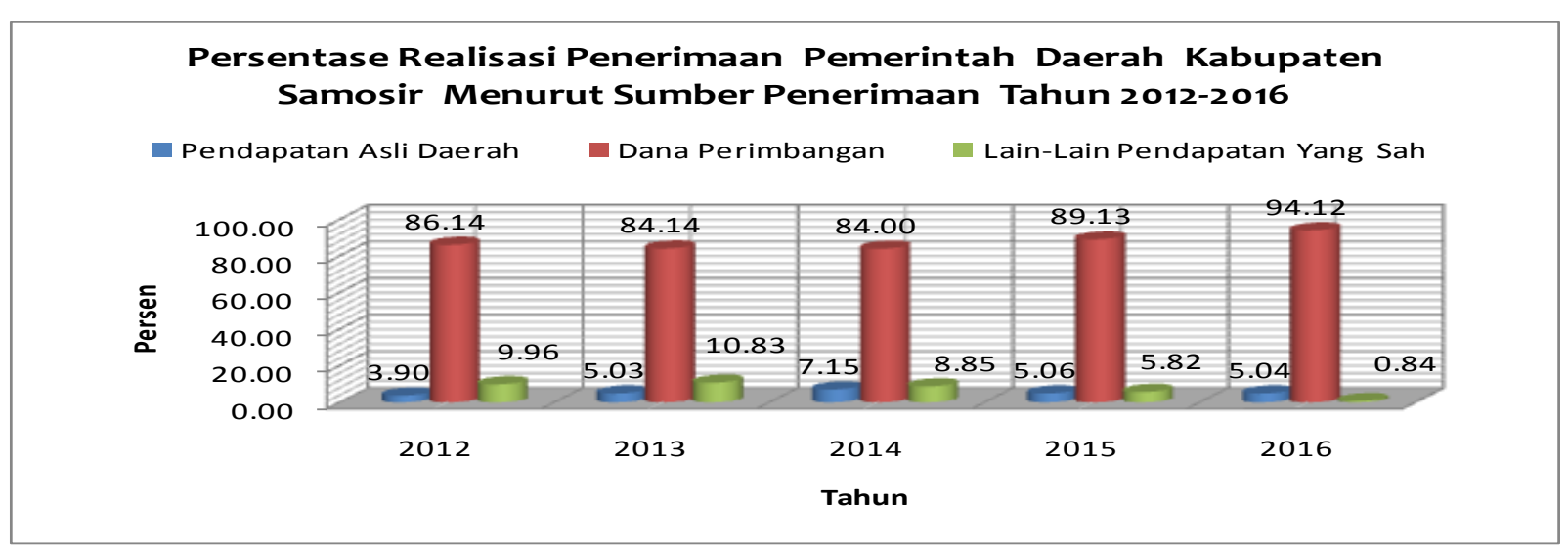

Gambar 1.Persentase Realisasi Penerimaan Menurut Jenis Penerimaan di Kabupaten Samosir Tahun 2012-2016

Berdasarkan Gambar 1 di atas nampak bahwatingkat persentase Pendapatan Asli Daerah selama ini masih belum cukup memadai dalam membiayai pembangunan sebuah daerah otonom karena persentase penerimaan asli daerah tahun 2012-2015 secara rata-rata masih mencapai 5,23 persen. Oleh karena itu, Pemerintah Kabupaten Samosir menganggap perlu mengadakan usaha-usaha lain guna menambah sumber-sumber pendapatan asli daerah.Sesuai perkembangan keadaan saat ini, usaha-usaha yang lebih tepat dan memungkinkan serta dapat diandalkan untuk menambah sumber pendapatan daerah adalah mengelola pengusahaan dengan prinsip ekonomi perusahaan dengan mendirikan Badan Usaha Milik Daerah. Undang-Undang Nomor 23 Tahun 2014 tentang Pemerintahan Daerah dan Undang-Undang Nomor 33 Tahun 2004 tentang Perimbangan Keuangan Antara Pemerintah Pusat dan Pemerintahan Daerah, salah satu sumber Pendapatan Asli Daerah diperoleh antara lain dari hasil pengelolaan kekayaan daerah yang dipisahkan, yang antara lain pemisahaan kekayaan daerah tersebut dimasukkan menjadi penyertaan modal dalam Badan Usaha Milik Daerah (BUMD).

Dengan pendirian BUMD diharapkan ikut berperan dalam menghasilkan barang dan/atau jasa yang diperlukan dalam rangka mewujudkan sebesar-besarnya kemakmuran masyarakat daerah. Oleh karena itu, ruang lingkup BUMD yang ada tidak terfokus pada satu bidang tetapi dapat melakukan usaha-usaha di bidang pembangunan, agrobisnis, industri strategis, konstruksi, properti, konsultan, jasa/perdagangan, telekomunikasi perhubungan (transportasi darat, laut dan udara), energi dan sumber daya mineral, kelautan dan perikanan, pariwista, penerbangan, infrastruktur, perbankan, investasi, asuransi, dan usaha lain sesuai kebutuhan sebagai upaya ekstensifikasi pendapatan daerah maupun untuk memenuhi kebutuhan masyarakat. Pada sisi lain, BUMD juga diposisikan sebagai badan usaha yang diupayakan untuk tetap mandiri dan untuk mendapatkan laba sehingga dapat menunjang kelangsungan usaha BUMD untuk meningkatkan kesejahteraan masyarakat di daerah otonom. Untuk dapat mengoptimalkan perannya dan mampu mempertahankan keberadaannya dalam perkembangan ekonomi dunia yang semakin terbuka dan kompetitif di BUMD, perlu menumbuhkan budaya profesionalisme antara lain melalui pembinaan pengurusan dan pengawasannya yang dilakukan berdasarkan prinsip-prinsip tata-kelola perusahaan yang baik (good corporate governance). Dengan demikian tujuan Pemerintah daerah mendirikan Badan Usaha Milik Daerah (BUMD) atau Perusahaan Daerah (PD) untuk turut serta melaksanakan pembangunan Daerah khususnya dan pembangunan ekonomi nasional umumnya dalam rangka untuk memenuhi kebutuhan rakyat dengan mengutamakan industrialisasi dan ketenteraman serta kesenangan kerja dalam perusahaan, menuju masyarakat yang adil dan makmur. 
Kabupaten Samosir merupakan salah satu dari 33 pemerintah Kabupaten/Kota yang ada di Sumatera Utara yang hingga saat ini masih belum ada mengelola Badan usaha Milik Daerah.Walaupun ada Perusahaan Daerah Air Minum (PDAM) Tirtanadi Cabang Samosir merupakan salah satu cabang pelayanan air minum Perusahaan Daerah Air Minum (PDAM) Tirtanadi Provinsi Sumatera Utara yang melayani kebutuhan air minum masyarakat Kabupaten Samosir dan sekitarnya.PDAM Tirtanadi cabang Samosir merupakan salah satu kerjasama operasi dengan Pemerintah Daerah di Provinsi Sumatera Utara.Kerjasama ini dimaksudkan untuk meningkatkan pelayanan air bersih kepada masyarakat sebagaimana diatur dalam Perda No. 3 Tahun 1999.

Berdasarkan latar belakang diatas, Pemerintah Kabupaten Samosir bersama-sama dengan seluruh elemen masyarakat di daerah memiliki keyakinan bahwa berbagai potensi kekayaan daerah yang ada dapat dikelola melalui pembentukan BUMD Aneka Usaha yang berorientasi pada kaedah-kaedah bisnis yang profesional dan akuntabel. Oleh karenanya sebagai upaya ke arah itu, pembentukan sebuah BUMD Aneka usaha di Kabupaten Samosir merupakan sebuah keniscayaan yang perlu didukung oleh sebuah perangkat hukum di daerah maka perlu adanya kajian tentang pembentukan BUMD yang dituangkan dalam naskah akademik sebagai syarat pembentukan Rancangan Peraturan tentang Pembentukan Badan Usaha Milik Daerah Kabupaten Samosir yang segala sesuatu kajian akademik tentang itu sebagaimana tertuang dalam naskah akademik ini. Berdasarkan latar belakang yang diuraikan diatas, maka permasalahannya dapat dirumuskan sebagai berikut:Bagaimanakah kelayakan pembentukan BUMD Aneka Usaha di Kabupaten Samosir?

\section{TINJAUAN PUSTAKA}

\section{A. Investasi}

Secara umum, investasi merupakan penanaman modal (baik modal tetap maupun modal tidak tetap) yang digunakan dalam proses produksi untuk memperoleh keuntungan suatu perusahaan. Menurut Husnan dan Swarsono(2001) bahwa "investasi adalah proses pengolahan uang". Menurut Halim (2005), investasi hakekatnya merupakan penempatan sejumlah dana pada saat ini dengan harapan untuk memperoleh di masa mendatang. Lebih jauh lagi ekonom asal Amerika Paul R. Krugman dan Maurice Obstfeld dalam Husnan (2001), mengatakan bahwa bagian output yang digunkan oleh perusahaan-perusahaan swasta guna menghasilkan output di masa mendatang ini bisa disebut sebagai investasi.

Menurut Husnan (2001) bahwa asal-usul investasi tidak mesti berasal dari bagian keuangan.Namun investasi juga dapat berasal dari bagian pemasaran (misal, membuka jaringan distribusi baru), bagian produksi (mengganti mesin lama dengan mesin baru), dan melibatkan berbagai bagian (meluncurkan produk baru, mendirikan pabrik baru).Sebuah investasi diperlukan untuk kegiatan berjaga-jaga dalam menghadapi peristiwa usaha yang tidak terduuga, dan bisa juga untuk memenuhi kebutuhan hidup.Untuk memperoleh investasi diperlukan modal dasar, yaitu dapat berupa uang, motivasi atau semangat.Oleh karena itu sebuah investasi tidak dapat terlepas dari suatu kegiatan bisnis dan merupakan aspek yang utama untuk lahirnya suatu usaha. Untuk mencapai suatu efisiensi dan efektivitas dalam keputusan maka diperlukan ketegasan akan tujuan yang diharapkan. Begitu pula halnya dalam bidang investasi kita perlu menetapkan tujuan yang hendak dicapai yaitu (Weston dan Copeland, 2007): (a) terciptanya keberlanjutan (continuity) dalam investasi tersebut, (b) terciptanya profit yang maksimum atau keuntungan yang diharapkan (profitactual), (c) terciptanya kemakmuran bagi para pemegang saham, (d) turut memberikan andil bagi pembangunan bangsa.

\section{B. Studi Kelayakan Bisnis}

Proyek investasi pada umumnya membutuhkan dana yang tidak sedikit dan berpengaruh bagi perusahaan dalam jangka waktu yang panjang, karena itu perlu dilakukan 
studi kelayakan bisnis agar dana yang telah diinvestasikan tidak terbuang percuma. Studi kelayakan bisnis dapat diartikan sebagai penelitian tentang akan didirikan atau perluasan suatu proyek guna mengetahui apakah layak atau tidaknya proyek tersebut dilaksanakan atau menguntungkan. Studi kelayakan bisnis bila dilakukan secara professional akan dapat berperan penting dalam proses pengambilan keputusan investasi.Menurut Kasmir dan Jakfar (2012), Kelayakan artinya penelitian yang dilakukan secara mendalam untuk menentukan apakah usaha yang akan dijalankan akan memberikan manfaat yang lebih besar dibandingkan dengan biaya yang akan dikeluarkan. Sedangkan bisnis adalah usaha yang dijalankan yang tujuan utamanya untuk memperoleh keuntungan. Dengan demikian, dapat disimpulkan bahwa pengertian Studi Kelayakan Bisnis adalah suatu kegiatan yang mempelajari secara mendalam tentang suatu usaha atau bisnis yanga akan dijalankan, dalam rangka menentukan layak atau tidak usaha tersebut dijalankan.Menurut Umar (2014) bahwa studi kelayakan bisnis merupakan penelitian terhadap rencana bisnis yang tidak hanya menganalisis layak atau tidaknya bisnis dibangun, tetapi juga saat dioperasionalkan secara rutin dalam rangka pencapaian keuntungan yang maksimal untuk waktu yang tidak ditentukan.Studi kelayakan biasanya digolongkan menjadi dua bagian yang berdasarkan pada orientasi yang diharapkan oleh satu perusahaan yaitu berdasarkan orientasi laba dan orientasi tidak pada laba.

\section{Tujuan Studi Kelayakan Bisnis}

Menurut Kasmir dan Jakfar (2012:13) ada lima tujuan dari studi kelayakan bisnis, yaitu : (a) menghindari resiko kerugian, (b) memudahkan perencanaan, (c) memudahkan pelaksanaan pekerjaan, (d) memudahkan pengawasan, (e) Memudahkan pengendalian.

\section{Aspek-Aspek Studi Kelayakan Bisnis}

1. Aspek Hukum.

Menurut Kasmir dan Jakfar (2012), untuk memulai studi kelayakan suatu usaha pada umumnya dimulai dari aspek hukum.Tujuan dari aspek hukum adalah untuk meneliti keabsahan, kesempurnaan, dan keaslian dari dokumen-dokumen yang dimiliki.Penelitian keabsahan dokumen dapat dilakukan sesuai dengan lembaga yang mengeluarkan dan yang mengesahkan dokumen yang bersangkutan.Penelitian ini sangat penting mengingat sebelum usaha tersebut dijalankan, maka segala prosedur yang berkaitan dengan izin-izin atau berbagai persyaratan harus terlebih dahulu sudah terpenuhi. Adapun dokumen yang perlu diteliti keabsahan, kesempurnaan dan keasliannya meliputi badan hukum, izin-izin yang dimiliki, sertifikat tanah atau dokumen lainnya yang mendukung kegiatan usaha tersebut.

\section{Aspek Pemasaran dan Pasar.}

Pemasaran merupakan ujung tombak perusahaan.Dalam dunia persaingan yang semakin ketat, perusahaan dituntut agar tetap bertahan hidup dan berkembang.Oleh karena itu seorang pemasar dituntut untuk memahami permasalahan pokok di bidangnya dan menyusun strategi adgar dapat mencapai tujuan perusahaan.Menurut Stanton dalam Subagyo (2008), pemasaran adalah suatu sistem total dari kegiatan bisnis yang dirancang untuk merencanakan, menentukan harga, promosi dan mendistribusikan barang-barang yang dapat memuaskan keinginan dan mencapai pasar sasaran serta tujuan perusahaan. Pengertian pasar secara sederhana dapat diartikan sebagai tempat bertemunya para penjual dan pembeli untuk melakukan transaksi.Pengertian ini mengandung arti pasar memiliki tempat atau lokasi tertentu sehingga memungkinkan pembeli dan penjual bertemu untuk melakukan transaksi jual beli produk baik barang maupun jasa.Pasar dan pemasaran merupakan dua sisi yang tidak dapat dipisahkan satu sama lainnya. Pasar dan pemasaran memiliki tingkat ketergantungan yang tinggi dan saling mempengaruhi satu sama lainnya. 
Dengan kata lain, setiap adanya pasar selalu diikuti oleh pemasaran dan setiap kegiatan pemasaran adalah untuk mencari atau menciptakan pasar Afandi (2006).

\section{Aspek Keuangan}

Menurut Hartono dan Murzito (2002), penelitian dalam aspek ini dilakukan untuk menilai biaya-biaya apa saja yang akan dikeluarkan dan seberapa besar biaya-biaya yang akan dikeluarkan. Kemudian juga meneliti seberapa besar pendapatan yang akan diterima jika usaha dijalankan. Dari banyaknya aspek penilaian kelayakan bisnis, maka aspek keuangan dilihat sebagai aspek yang memiliki pengaruh besar karena keputusan keuangan bukan hanya berdampak secara jangka pendek namun juga bisa berdampak secara jangka panjang.

Menurut Kasmir dan Jakfar (2012), investasi yang dilakukan dalam berbagai bidang bisnis (usaha), tentu memerlukan sejumlah modal, disamping keahlian lainnya.Modal yang digunakan untuk membiayai suatu bisnis, mulai dari prainvestasi, biaya investasi dalam aktiva tetap, hingga modal kerja.Modal digunakan untuk membiayai biaya investasi seperti pengurusan izin-izin dan pembuatan studi usaha.Kemudian selanjutnya yang harus dikeluarkan adalah untuk pembelian aktiva tetap seperti pembelian tanah, pendirian bangunan atau gedung, pembelian mesin-mesin, dan aktiva tetap lainnya. Modal juga digunakan untuk biaya operasi pada saat bisnis tersebut dijalankan, misalnya untuk biaya bahan baku, gaji, dan biaya operasi lainnya.

\section{E. Sumber-Sumber Dana}

Menurut Kasmir dan Jakfar (2012), untuk mendanai suatu kegiatan investasi biasanya diperlukan dana yang relatif besar. Perolehan dana dapat dicari dari berbagai sumber dana yang ada, misalnya modal sendiri dan atau modal asing (modal pinjaman). Dalam praktiknya kebutuhan modal untuk melakukan investasi terdiri dari dua macam, yaitu modal investasi dan modal kerja.Modal investasi digunakan untuk membeli aktiva tetap, misalnya tanah, bangunan, mesin-mesin, peralatan, serta inventaris lainnya dan biasanya modal investasi diperoleh dari pinjaman yang berjangka waktu panjang.

Kemudian modal kerja yaitu modal yang digunakan untuk membiayai operasional perusahaan selama perusahaan beroperasi.Jangka waktu penggunaan modal kerja relatif pendek, yaitu untuk satu atau beberapa siklus operasi perusahaan. Modal kerja digunakan untuk kepentingan membeli bahan baku, membayar gaji karyawan dan biaya pemeliharaan serta biaya-biaya lainnya. Dilihat dari segi sumber asalanya, modal dibagi dua macam yaitu: (Kasmir dan Jakfar (2012).

1. Modal Asing atau modal pinjaman merupakan modal yang diperoleh dari pihak luar perusahaan dan biasanya diperoleh secara pinjaman. Kemudian adanya kewajiban untuk mengembalikan pinjaman setelah jangka waktu tertentu sesuai perjanjian sebelumnya.Sumber dana dari modal asing dapat diperoleh antara lain dari : (a) pinjaman dari dunia perbankan, (b) pinjaman dari lembaga keuangan seperti perusahaan modal ventura, asuransi, leasing, atau lembaga keuangan lainnya, dan (c) pinjaman dari perusahaan nonbank.

2. Modal Sendiriadalah modal yang diperoleh dari pemilik perusahaan dengan cara mengeluarkan saham baik secara tertutup atau terbuka. Keuntungan menggunakan modal sendiri untuk membiayai suatu usaha adalah tidak adanya beban biaya bunga seperti modal pinjaman.

3. Arus Kas (Cash Flow), merupakan arus kas atau aliran kas yang ada diperusahaan dalam suatu periode tertentu.

Uang masuk dapat berupa pinjaman dari lembaga keuangan atau hibah dari pihak tertentu.Uang masuk juga dapat diperoleh dari penghasilan atau pendapatan yang diperoleh dari yang berhubungan langsung dengan usaha yang sedang dijalankan seperti penjualan. Uang masuk juga bisa pula berasal dari pendapatan lainnya yang bukan dari usaha 
utama.Uang keluar merupakan sejumlah uang yang dikeluarkan perusahaan dalam suatu periode, baik yang langsung berhubungan dengan usaha yang dijalankan, maupun yang tidak ada hubungan sama sekali dengan usaha utama. Uang keluar ini merupakan biaya-biaya yang harus dikeluarkan perusahaan untuk berbagai keperluan yang berkaitan dengan kegiatan usaha, seperti pembayaran cicilan utang dan bunga pinjaman, biaya produksi, biaya tenaga kerja, dan biayapemasaran. Menurut Setiawan (2002), Cash Flow atau arus kas pada suatu investasi dapat dibedakan atas 3 (tiga) bagian yaitu:

1. Arus kas awal (Intial Cash Flows). Arus kas yang terjadi pada awal investor melaksanakan pendirian atau pembangunan sebuah usaha/ proyek.Arus kas awal ini lazim didefinisikan terjadi pada periode ke-0 dan pengeluaran kas yang bersangkutan berkaitan dengan pelaksanaan pendirian atau pembangunan sebuah usaha/ proyek investasi.

2. Arus kas operasi (operating cash flows). Arus kas yang terjadi pada sebuah investasi/ proyek atau perusahaan yang sudah dan sedang beroperasi.Untuk menghitung arus kas operasi dapat dilakukan dengan cara, yaitu:

a. Apabila pembiayaan investasi/fproyek menggunakan $100 \%$ modal sendiri, artinya tanpa modal pinjaman, maka perhitungan arus kas operasi dapat dilakukan dengan menggunakan rumus sebagai berikut:

Arus Kas Operasional = Laba bersih setelah pajak + Depresiasi.

b. Apabila pembiayaan investasi/ proyek menggunakan kombinasi modal sendiri dan pinjaman, artinya pembiayaan investasi/ proyek tidak seluruhnya menggunakan modal sendiri melainkan ada menggunakan modal pinjaman, maka perhitungan arus kas operasi dapat dilakukandengan menggunakan rumus sebagai berikut:

Arus Kas Operasional $=$ Laba bersih setelah pajak + Depresiasi +Bunga $(1-$ Pajak $)$.

c. Arus kas terminal (terminal cash flows). Arus kas yang terjadi pada saat sebuah investasi/ proyek sudah tiba pada akhir usia ekonomis, meliputi penerimaan nilai sisa investasi/ proyek dan pemulihan atau pengembalian modal kerja.

\section{METODOLOGI PENELITIAN}

\section{A. Ruang Lingkup.}

Ruang lingkup kajian kelayakan pembentukan BUMD Aneka Usaha di Kabupaten Samosir adalah menyangkut aspek aspek finansial usaha transportasi, usaha parawisata dan usaha konstruksi di Kabupaten Samosir.

\section{B. Jenis dan Sumber Data}

Data yang digunakan dalam penelitian ini adalah data sekunder dan data primer.Data sekunder meliputi data asset konstruksi, data transportasi dan data parawisata yang berasal dari OPD terkait serta Samosir dalam Angka Tahun 2015-2018.Sedangkan data primer dikumpulkan melalui wawancana yang didapatkan dari masyakat dan pejabat SKPD yang terkait Kabupaten Samosir.

\section{Metode Pengumpulan Data}

Pengumpulan data diperoleh melalui telaah kepustakaan dan hasil publikasi dengan metode dokumentasi. Adapun data yang dikumpulkan adalah: data asset konstruksi, parawisata dan transportasi tahun 2015-2017, pendapatan perkapita Kabupaten Samosir sejak Tahun 2015 - 2016 dan sumber Penerimaan Kabupaten Samosir sejak Tahun 2015-2016.

\section{Definisi Operasional Variabel}

Definisi operasional variable dapat dijelaskan sebagai berikut:

1. Usaha konstruksi yakni kegiatan menyewakan alat-alat berat kepada pemerintah dan masyarakat dalam pembangunan baik sebagai perorangan, perusahaan dan Pemerintah Kabupaten Samosir. 
2. Usaha Transpsortasi kegiatan denganmenawarkan jasa transportasi kepada masyarakat dengan trayek dari Pangururan (Samosir) - Bandara Silangit (Sibororng-borong Kabupaten Tapanuli Utara) PP.

3. Usaha Pariwisata kegiatandengan menyewakan Kapal Wisata Samosir, Penginapan Wisma Maduma/ Hotel Tuktuk View Inn, Aula Wisma Maduma/ Tuktuk View Inn, Gedung Kesenian, Pondok Remaja Lagundi kepada masyarakat dan Pemerintah Kabupaten Samosir

\section{E. Metode Analisis}

Menurut Brigham dan Houston (2001) dan Horne and Wachowicz (2000) Metode analisis yang digunakan untuk menilai kelayakan bisnis dari Aspek finansialantara lain:

1. Benefit Cost Ratio (BCR), yaitu merupakan suatu analisis yang diperlukan untuk melihatsejauh mana perbandingan antara nilai manfaat terhadap nilai biaya dilihat pada kondisi nilai sekarang/present value (PV). Ukuran dari penilaian suatu kelayakan proyek dengan metode ini adalah:

a. Jika BCR $>1$, proyek dapat dikatakan layak dikerjakan.

b. Sebaliknya, jika nilai BCR $<1$, proyek tersebut tidak layak untuk dikerjakan.

Rumus perhitungan $B C R$ ini adalah:

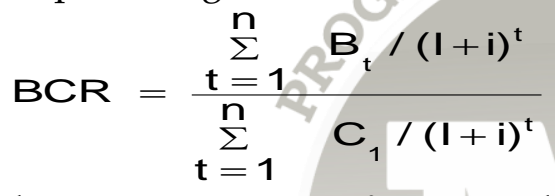

dimana: $\mathrm{B}_{\mathrm{t}} \quad=$ Benefit setiap tahun

$$
\begin{aligned}
\mathrm{C}_{\mathrm{t}} & =\text { Biaya (cost) setiap tahun } \\
\mathrm{t} & =\text { Tahun ke } 1,2,3, \ldots \ldots . \mathrm{n} \\
\mathrm{n} & =\text { Jumlah tahun } \\
\mathrm{i} & =\text { Interest Rate }
\end{aligned}
$$

2. Net Present Value (NPV) yaitu merupakan nilai dari proyek yang bersangkutan yang diperoleh berdasarkan selisih antara cash flow yang dihasilkan terhadap investasi yang dikeluarkan. Kriteria yang dipakai adalah sebagai berikut:

a. NPV $>0$ (nol) $\rightarrow$ usaha/ proyek layak (feasible) untuk dilaksanakan

b. NPV < 0 (nol) $\rightarrow$ usaha/proyek tidak layak (feasible) untuk dilaksanakan

c. $\mathrm{NPV}=0$ (nol) $\rightarrow$ usaha/proyek berada dalam keadaan BEP dimana TR=TC dalam bentukpresent value.

Rumus untuk perhitungan NPV ini adalah:

$$
\begin{aligned}
& \mathrm{NPV}=-\mathrm{A} 0+\sum_{t=1}^{n} \frac{A t}{(1+i)^{t}} \\
& \text { Dimana: At = Benefit setiap tahun } \\
& \text { Ao }=\text { Initial investement } \\
& \mathrm{t} \quad=\text { Tahun ke } 1,2,3, \ldots . . \mathrm{n} \\
& \mathrm{n}=\text { Jumlah tahun } \\
& \mathrm{i} \quad=\text { Interest rate/biaya modal }
\end{aligned}
$$

3. Internal Rate or Return (IRR) yaitu merupakan tingkat diskon rate yang menghasilkan NPV sama dengan nol. Kriteria yang digunakan pada metode ini adalah:

a. Jika hasil perhitungan IRR lebih besar dari discount factor, maka dapat dikatakan investasi yang akan dilakukan layak untuk dilakukan.

b. Jika sama dengan discount factor, dikatakan investasi yang ditanamkan akan balik modal.

c. Sedangkan jika IRR lebih kecil dari discount factor maka investasi yang ditanamkan tidak layak.

Perhitungan nilai $I R R$ dapat diperoleh dengan menggunakan rumus sebagai berikut: 


$$
\begin{aligned}
\operatorname{IRR}=\sum_{i=1}^{n} \frac{\left(B_{t}-C_{t}\right)}{(1+i)^{t}}=0 \\
\text { dimana: } \mathrm{B}_{\mathrm{t}}=\text { Benefit setiap tahun } \\
\mathrm{C}_{\mathrm{t}}=\text { Biaya (cost) setiap tahun } \\
\mathrm{T}=\text { Tahun ke } 1,2,3, \ldots . . . . \mathrm{n} \\
\mathrm{N} \quad=\text { Jumlah tahun } \\
\mathrm{i} \quad=\text { Interest rate/biaya modal }
\end{aligned}
$$

$I R R$ merupakan tingkat suku bunga/biaya modal yang diperhitungkan mengembalikan nilai investasi selama umur proyek.

4. Payback Period $(P P)$ yaitu menunjukkan waktu yang diperlukan proyek untuk menghimpun dana internal guna mengembalikan jumlah dana yang telah diinvestasikan dalam proyek.

Rumus yang digunakan untuk menghitung payback period adalah sebagai berikut:

$$
\begin{aligned}
& \mathbf{a}-\mathbf{b}
\end{aligned}
$$

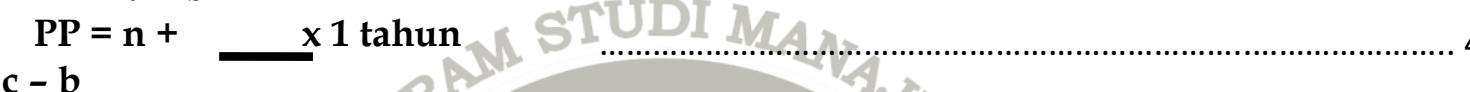

$$
\begin{aligned}
& \text { dimana }: \mathrm{n}=\text { Tahun terakhir dimana jumlah arus kas masih belum bisa menutup } \\
& \text { investasi mula-mula } \\
& \mathrm{a} \quad=\text { Jumlah investasi mula-mula. } \\
& \mathrm{B}=\text { Jumlah kumulatif arus kas pada tahun ke }-\mathrm{n} \\
& \mathrm{C} \quad=\text { Jumlah kumulatif arus kas pada tahun ke } \mathrm{n}+1
\end{aligned}
$$

Untuk mengetahui kelayakan suatu proyek berdasarkan payback period, maka angka atau nilai payback period proyek tersebut harus dibandingkan dengan payback period yang disyaratkan/diinginkan oleh investor atau dapat juga dibandingkan dengan payback period proyek sejenis yang sudah ada sebelumnya.

\section{HASIL DAN PEMBAHASAN}

Strategi pembentukan perusahaan grup tidak dapat dilepasakan dari realitas bisnis yang terjadi ketika pengelolaan usaha melalui konstruksi perusahaan grup dianggap lebih memberikan manfaat ekonomi dibandingkan déngan perusahaan tunggal.Secara umumada dua alasan utama pembentukan atau pengembangan perusahaan grup. Alasan yang pertama adalah sebagai upaya mengakomodasiperaturan perundang-undangan.Alasan yang kedua adalah sebagai upaya strategi perusahaanuntuk memperoleh manfaat ekonomi sebagai konstruksi perusahaan grup.Dalam rangka pengelolaan BUMD secara profesional dan sesuai dengan prinsip -prinsip good corporate governance serta sesuai dengantujuan revitalisasi BUMD, maka diperlukan sebuah strategi pengelolaan BUMD khususnya yang berbentuk perseroan dengan menggunakan strategi pembentukan perusahaan grup.

\section{A. Divisi Usaha BUMD Aneka Usaha di Kabupaten Samosir}

Adapun unit usaha yang akan dibentuk dalam BUMD Aneka Usaha di Kabupaten Samosir di antaranya adalah:

a. Divisi Konstruksi. Berdasarkan kategori divisi konstruksi adalah menjadi penyedia jasa dengan Jenis Asset akan dikelola oleh BUMD yakni 9 buah Dump Truck, 2 buah Vibrator (compactor) Roller 6-8 ton, 1 buah Truck Trado, 4 buah track excavator, 1 buah Buldozer, 1 buah Whell Loader, 1 buah Three Whell Roller dan 2 buah Motor Greder, dengan umur ekonomis masing-masing 10 tahun dan dengan nilai investasi sebanyak $\mathrm{Rp}$ 19.854.059.804.Realisasipemakaian alat-alat berat oleh OPD PURR pada tahun 2015, 2016 dan 2017 secara rata-rata selama 19 hari, 62 hari dan 87 hari. Realisasi penerimaan pemakaian alat-alat berat Pemerintah Kabupaten Samosir pada tahun 2015 adalah sebesar Rp 10.120.000, tahun 2016 menjadi sebesar Rp 168.281.000 dan tahun 2017 menjadi sebesar 
Rp 235.000.000.Realisasi biaya operasional alat-alat berat milik Pemerintah Kabupaten Samosir sejak tahun 2015 adalah sebesar Rp 4.397.302.942, dan tahun 2016 menurun menjadi sebesar Rp 4.311.118.960 atau 1,96 persen, kemudian pada tahun 2017 meningkat kembali menjadi sebesar Rp 4.482.644.439 atau 3.97 persen.

b. Usaha Pariwisata. Adapun jenis usaha pariwisata BUMD Kabupaten Samosir adalah Transportasi, Hotel, Aula, Gedung Kesenian dan Pondok Remaja yang selama ini dikelola oleh Dinas Pariwisata diantaranya adalah KapalWisataSamosir, WismaMaduma/Hotel Tuktuk View Inn, Aula WismaMaduma/Tuktuk View Inn, Gedung Kesenian dan Pondok Remaja Lagundi dengan nilai investasi sebesar $\mathrm{Rp}$ 5.594.828.433. Realisasi penerimaandiperkirakan dari unit usaha Kapal Wisata Samosir diperkirakan pertahun menjadi Rp 365.000.000.-,sedangkanrealisasi penerimaan dari sewa kamar Penginapan Wisma Maduma/Hotel Tuktuk View Inn pada tahun 2016 sebesar Rp 12.000.000 dan meningkat pada tahun 2017 menjadi Rp 25.860.000 atau sebesar 115.5 persen hal ini sejalan dengan peningkatan kapasitas terpakai aula pada tahun 2017 dari 2 kali/tahun menjadi10 kali/tahun. Sedangkan penerimaan dari Gedung Kesenian dan Pondok Remaja Lagundi pada tahun 2015-2017 adalah nihil. Estimasi biaya operasional Kapal Wisata Samosir pada tahun 2018 sebesar $\operatorname{Rp}$ 290.000.000, dan pada tahun 2019 meningkat menjadi Rp 471.350.000 atau 62.53 persen. Sedangkan realisasi biaya operasional dari Penginapan WismaMaduma/Hotel Tuktuk View Inn, Aula WismaMaduma/ Tuktuk View Inn, Gedung Kesenian dan Pondok Remaja Lagundi sejak tahun 2015-2017 adalah nihil.

c. Usaha Transportasi. Adapun jenis asset transportasi milik Pemerintah Kabupaten Samosir yang selama ini dikelola oleh Dinas Perhubungan yang kemudian ada 2 unit dengan tahun pembuatan 2016, nilai investai sebesar Rp 1.234.000.000, dan dengan umur ekonomis 5 tahun. Estimasi penerimaan dari transportasi Milik Pemerintah Kabupaten Samosir pada Bulan April 2018 adalah sebesar Rp 30.300.000 dan pada tahun 2018 menjadi $9 * \operatorname{Rp} 30.300 .000=\operatorname{Rp} 272.700 .000$, sedangkan biaya operasional Transportasi Milik Pemerintah Kabupaten Samosir selama bulan April 2018 adalah sebesar Rp 73.666.000.atau pada tahun 2018 menjadi sebesar 9* Rp 73.666.000 Rp 662.994.000.

\section{B. Pembahasan}

Sesuai dengan uraian di atas bahwa untuk pembentukanBUMD Aneka Usaha Kabupaten Samosir, mengikutsertakan beberapa asset yang selama ini dikelola oleh beberapa OPD dalam pembangunan Kabupaten Samosir.Beberapa divisi unit usaha dalam pengelolaanBUMD Aneka Usaha sebagai Holding Company di antaranya adalah sebagai berikut: (1) Divisi Konstruksi dengan 21 asset, Pada divisi Konstruksi kegiatannya dengan menyewakan alat-alat berat kepada pemerintah dan masyarakat dalam pembangunan baik sebagai perorangan, perusahaan dan Pemerintah Kabupaten Samosir; (2) Divisi Pariwisata dengan 5 asset, Pada divisi Pariwisata dengan menyewakan KapalWisataSamosir, Penginapan Wisma Maduma/Hotel Tuktuk View Inn, Aula Wisma Maduma/ Tuktuk View Inn, Gedung Kesenian, Pondok Remaja Lagundi kepada masyarakat dan Pemerintah Kabupaten Samosir, dan (3) Divisi Transportasi dengan 2 asset, pada divisi Transportasi dengan menawarkan jasa transportasi kepada masyarakat dengan trayek dari Pangururan (Samosir) - Bandara Silangit (Sibororng-borong Kabupaten Tapanuli Utara) PP.

PembentukanBUMD Kabupaten Samosir terdiri atas 3 divisi, yaitu divisi konstruksi, divisi pariwisata dan divisi transportasi dengan nilai investasi untuk 10 tahun untuk ketiga divisi adalah $\mathrm{Rp}$ 19.854.059.804 + Rp 5.594.828.433 + Rp 2.390.381.000 + Rp 1.234.000.000 $+1.234 .000 .000 \mathrm{Rp}$ 30.307.269.237. Perhitungan Benefit, manfaat atau benefit dari Pengelolaan BUMD Kabupaten Samosir sejak Tahun 2019 berasal daridivisi Konstruksi, divisi Pariwisata dan divisi Transportasi dengan asumsi sebagai berikut ini:

1. Divisi Konstruksi: Kapasitas terpakai asset divisi konstruksi sejak dikelola oleh BUMD minimal harus bias mencapai rata-rata 50 persen dengan pendapatan Rp. 9.000.000.000, 
petumbuhan pemakaian kapasitas asset per tahun 10 persen, dan setiap dua tahun tarif sewa asset naik 5 persen.

2. Divisi Pariwisata: pendapatan Kapal Wisata Samosir Rp 3 juta per hari, setiap tahun pendapatan Kapal Wisata naik 1 juta per hari, kapasitas terpakai Penginapan Wisma Maduma/Hotel Tuktuk View Inn minimal sebesar 10 persen dengan pendapatan Rp 30.000.000, setiap tahun kapasitas terpakainya penginapan Wisma Maduma/Hotel Tuktuk View Inn naik 10 persen, kapasitas pemakaian Aula Wisma Maduma/Tuktuk View Inn sebanyak 12 kali per tahun dengan pendapatan Rp 14.000.000, setiap 2 tahun Kapasitas pemakaian Aula Wisma Maduma/ Tuktuk View Inn bertambah 1 kali, Realisasi pemakaian Gedung Kesenian 2 kali setahun dengan pendapatan Rp 4000.000, setiap 2 tahun realisasi pemakaian Gedung Kesenian bertambah 1 kali, realisasi pemanfaatan Pondok Remaja Lagundi sebesar 8 persen dengan pendapatan Rp 8.000.000, dan setiap 2 tahun realisasi pemanfaatan Pondok Remaja lagundi naik 2 persen.

3. Divisi Transportasi: kapasitas jumlah penumpang sebesar 43 persen dengan pendapatan Rp 864.000.000, realisasi Jumlah penumpang transportasi setiap tahun naik 20 persen, dan setiap dua tahun sekali tarif penumpang transportasi naik 5 persen

Berdasarkan asumsi-asumsi di atas maka proyeksi pendapatan BUMD Aneka Usaha Kabupaten Samosir Tahun 2019-2028 di uraikan pada Tabel berikut.

Tabel 1. Proyeksi Pendapatan BUMD Kabupaten Samosir Tahun 2019 - 2028 (Rupiah)

\begin{tabular}{|c|c|c|c|c|}
\hline Tahun & Jasa Konstruksi & \multicolumn{1}{|c|}{ Jasa Pariwisata } & Jasa Transportasi & Total \\
\hline$[\mathbf{1}]$ & \multicolumn{1}{|c|}{$[\mathbf{2}]$} & {$[\mathbf{3}]$} & {$[\mathbf{4}]$} & {$[\mathbf{5}]$} \\
\hline 2019 & 9.000 .000 .000 & 1.151 .000 .000 & 864.000 .000 & 11.015 .000 .000 \\
\hline 2020 & 9.900 .000 .000 & 1.520 .400 .000 & 1.036 .800 .000 & 12.457 .200 .000 \\
\hline 2021 & 11.434 .500 .000 & 1.984 .490 .000 & 1.306 .368 .000 & 14.725 .358 .000 \\
\hline 2022 & 12.577 .950 .000 & 2.263 .564 .000 & 1.567 .641 .600 & 16.409 .155 .600 \\
\hline 2023 & 14.527 .532 .250 & 2.765 .170 .400 & 1.975 .228 .416 & 19.267 .931 .066 \\
\hline 2024 & 15.980 .285 .475 & 3.008 .862 .440 & 2.370 .274 .099 & 21.359 .422 .014 \\
\hline 2025 & 18.457 .229 .724 & 3.548 .198 .684 & 2.986 .545 .365 & 24.991 .973 .773 \\
\hline 2026 & 20.302 .952 .696 & 3.756 .743 .552 & 3.583 .854 .438 & 27.643 .550 .686 \\
\hline 2027 & 23.449 .910 .364 & 4.334 .067 .908 & 4.515 .656 .592 & 32.299 .634 .863 \\
\hline 2028 & 25.794 .901 .400 & 4.507 .749 .698 & 5.418 .787 .910 & 35.721 .439 .009 \\
\hline
\end{tabular}

Sumber: Data diolah 2018

\section{Biaya Operasi/Pemeliharaan Tahunan (ANNUAL COST).}

Estimasi Biaya operasional tahunan didasarkan pada realisasi biaya operasional tahun 2015 dan 2016 untuk masing-masing divisi Konstruksi, divisi Pariwisata dan divisi Transportasi kemudian biaya operasional, biaya pemeliharaan dan biaya manajemen mengalami kenaikan sebesar $5 \%$ dari setiap tahunnya. Adapun biaya operasional, biaya pemeliharaan dan biaya manajemen BUMD Aneka Usaha Kabupaten Samosir Tahun 20192028 disajikan pada Tabel 2 berikut.

Tabel 2. Proyeksi Biaya Operasional dan Pemeliharaan BUMD Kabupaten Samosir Tahun 2019-2028

\begin{tabular}{|c|c|c|c|c|}
\hline Tahun & Jasa Konstruksi & Jasa Parawisata & Jasa Transportasi & Total \\
\hline$[\mathbf{1}]$ & {$[\mathbf{2}]$} & {$[\mathbf{3}]$} & {$[4]$} & {$[\mathbf{5}]$} \\
\hline 2019 & 4.500 .000 .000 & 824.350 .000 & $637.392 .000,00$ & 824.350 .000 \\
\hline 2020 & 4.725 .000 .000 & 865.567 .500 & $669.261 .600,00$ & 65.567 .500 \\
\hline 2021 & 4.961 .250 .000 & 908.845 .875 & $702.724 .680,00$ & 08.845 .875 \\
\hline
\end{tabular}


Volume 19 Nomor 1

\begin{tabular}{|c|l|l|l|c|}
\hline Tahun & Jasa Konstruksi & Jasa Parawisata & Jasa Transportasi & Total \\
\hline$[\mathbf{1}]$ & \multicolumn{1}{|c}{]} & {$[\mathbf{3}]$} & {$[\mathbf{4}]$} & {$[\mathbf{5}]$} \\
\hline 2022 & 5.209 .312 .500 & 954.288 .169 & $737.860 .914,00$ & 54.288 .169 \\
\hline 2023 & 5.469 .778 .125 & 1.002 .002 .577 & $774.753 .959,70$ & 1.002 .002 .577 \\
\hline 2024 & 5.743 .267 .031 & 1.052 .102 .706 & $813.491 .657,69$ & 1.052 .102 .706 \\
\hline 2025 & 6.030 .430 .383 & 1.104 .707 .841 & $854.166 .240,57$ & 1.104 .707 .841 \\
\hline 2026 & 6.331 .951 .902 & 1.159 .943 .233 & $896.874 .552,60$ & 1.159 .943 .233 \\
\hline 2027 & 6.648 .549 .497 & 1.217 .940 .395 & $941.718 .280,23$ & 1.217 .940 .395 \\
\hline 2028 & 6.980 .976 .972 & 1.278 .837 .415 & $988.804 .194,24$ & 1.278 .837 .415 \\
\hline
\end{tabular}

Sumber: Data diolah 2018

Tabel 3: Biaya Manajemen BUMD Tahun 2019

\begin{tabular}{|l|l|c|c|c|c|}
\hline No & & Satuan & Nilai & Jumlah & \multicolumn{1}{c|}{ Total (Rupiah) } \\
\hline$[\mathbf{1}]$ & \multicolumn{1}{|c|}{$[\mathbf{2 ]}$} & {$[3]$} & {$[4]$} & {$[5]$} & \multicolumn{1}{c|}{$[\mathbf{6 ]}$} \\
\hline 1 & Direktur & Bulan & 15.000 .000 & 1 Orang & 180.000 .000 \\
\hline 2 & Satuan Pengawas Internal & Tahun & 30.000 .000 & 1 Tim & 30.000 .000 \\
\hline 3 & Direktur & Bulan & 12.000 .000 & 2 Orang & 288.000 .000 \\
\hline 4 & Bagian & Bulan & 10.000 .000 & 5 Orang & 600.000 .000 \\
\hline
\end{tabular}

Berdasarkan Tabel 1 dan 2 di atas maka proyeksi Laba yang akan diperoleh BUMD Aneka Usaha Kabupaten Samosir Tahun 2019 - 2028 dapat diuraikan pada Tabel 4 berikut.

Tabel 4. Proyeksi Laba Pembentukan BUMD Kabupaten Samosir Tahun 2019-2028

\begin{tabular}{|l|l|l|l|}
\hline Tahun & \multicolumn{1}{|c|}{ Total Penerimaan } & \multicolumn{1}{c|}{ Total Biaya } & \multicolumn{1}{c|}{ Laba } \\
\hline \multicolumn{1}{|c|}{$[\mathbf{1}]$} & \multicolumn{1}{|c|}{$[\mathbf{2 ]}$} & {$[\mathbf{3}]$} & {$[\mathbf{4}]$} \\
\hline 2019 & 11.015 .000 .000 & 6.561 .742 .000 & 4.453 .258 .000 \\
\hline 2020 & 12.457 .200 .000 & 6.889 .829 .100 & 5.567 .370 .900 \\
\hline 2021 & 14.725 .358 .000 & 7.234 .320 .555 & 7.491 .037 .445 \\
\hline 2022 & 16.409 .155 .600 & 7.596 .036 .583 & 8.813 .119 .017 \\
\hline 2023 & 19.267 .931 .066 & 7.975 .838 .412 & 11.292 .092 .654 \\
\hline 2024 & 21.359 .422 .014 & 8.374 .630 .332 & 12.984 .791 .682 \\
\hline 2025 & 24.991 .973 .773 & 8.793 .361 .849 & 16.198 .611 .924 \\
\hline 2026 & 27.643 .550 .686 & 9.233 .029 .941 & 18.410 .520 .745 \\
\hline 2027 & 32.299 .634 .863 & 9.694 .681 .439 & 22.604 .953 .424 \\
\hline 2028 & 35.721 .439 .009 & 10.179 .415 .511 & 25.542 .023 .498 \\
\hline
\end{tabular}

Sumber: Data diolah 2018

\section{Perhitungan Kelayakan Pengelolaan BUMD Kabupaten Samosir}

Kelayakan pengelolaan BUMD Kabupaten Samosir dianalisis berdasarkan parameter keuangan berupa B/C ratio, NPV, PP, dan IRR. Sebagai discount factor atau tingkat pengembalian modal minimum pada kajian ini ditetapkan sebesar $10 \%$ per tahun dan periode proyek selama 10 tahun. Adapun perhitungan kelayakan dalam pengelolaan BUMD disajikan pada Tabel 5 sebagai berikut. 
Tabel 5: Nilai sekarang dari arus kas total masuk Pada BUMD Aneka Usaha Kabupaten Samosir

\begin{tabular}{|c|l|l|l|}
\hline Tahun & \multicolumn{1}{|c|}{ Arus Kas Masuk } & $\begin{array}{c}\text { Discount } \\
\text { Factor }\end{array}$ & Nilai Sekarang \\
\hline$[\mathbf{1}]$ & \multicolumn{1}{|c|}{$[\mathbf{2}]$} & \multicolumn{1}{|c|}{$[\mathbf{3}]$} & \multicolumn{1}{c|}{$[\mathbf{4}]$} \\
\hline 2019 & 6.753 .258 .000 & $\mathbf{0 , 9 0 9 1}$ & 6.139 .386 .848 \\
\hline 2020 & 7.867 .370 .900 & $\mathbf{0 , 8 2 6 4}$ & 6.501 .595 .312 \\
\hline 2021 & 9.791 .037 .445 & $\mathbf{0 , 7 5 1 3}$ & 7.356 .006 .432 \\
\hline 2022 & 11.113 .119 .017 & $\mathbf{0 , 6 8 3}$ & 7.590 .260 .289 \\
\hline 2023 & 13.592 .092 .654 & $\mathbf{0 , 6 2 0 9}$ & 8.439 .330 .329 \\
\hline 2024 & 15.284 .791 .682 & $\mathbf{0 , 5 6 4 5}$ & 8.628 .264 .904 \\
\hline 2025 & 18.498 .611 .924 & $\mathbf{0 , 5 1 3 2}$ & 9.493 .487 .639 \\
\hline 2026 & 20.710 .520 .745 & $\mathbf{0 , 4 6 6 5}$ & 9.661 .457 .928 \\
\hline 2027 & 24.904 .953 .424 & $\mathbf{0 , 4 2 4 1}$ & 10.562 .190 .747 \\
\hline 2028 & 27.842 .023 .498 & $\mathbf{0 , 3 8 5 5}$ & 10.733 .100 .058 \\
\hline & & & 85.105 .080 .486 \\
\hline
\end{tabular}

Sumber: Data diolah 2018

Berdasarkan Tabel 5. maka kelayakan pengelolaan BUMD Kabupaten Samosir berdasarkan parameter adalah sebagai brikut.

a. Benefit Cost Ratio (BCR), Hasil analisis menunjukkan bahwa untuk nilai $B C R=2,81$ lebih besar dari 1. Dengan demikian dapat dinyatakan bahwa proyek tersebut adalah layak atau menguntungkan.

b. Net Present Value (NPV), Hasil analisis menunjukkan bahwa untuk nilaiNPV $=\mathrm{Rp}$ 54.797.811.249 adalah positif. Dengan demikian dapat dinyatakan bahwa divisi tersebut adalah layak atau menguntungkan.

c. Internal Rate or Return (IRR), Hasil analisis menunjukkan bahwa nilai $I R R=34 \%$ adalah lebih besar dari Biaya Modal/Weighted Average Cost of Capital $\quad(W A C C)=10 \%$. Dengan demikian menurut kriteria IRR divisi tersebut adalah layak.

d. PAYBACK PERIOD $(P P)$, hasil analisis menyatakan bahwa untuk payback period proyek adalah kurang dari 4,2 tahun. Apabila dibandingkan dengan umur proyek yaitu 10 tahun.Dengan demikian menurut kriteria Payback period divisi tersebut adalah layak,

Dari perhitungan tersebut diatas diketahui bahwa periode pengembalian investasi dari ketiga divisi yang serta gabungan ketiga divisi pada BUMD Aneka Usaha di bawah umur proyek. Dengan demikian BUMD Aneka Usaha tersebut layak untuk dibentuk atau dapat diterima.

\section{KESIMPULAN DAN SARAN}

\section{A. Kesimpulan}

Berdasarkan hasil analisis mengenai rencana pembentukan BUMD Aneka Usaha di Kabupaten Samosir dapat ditarik beberapa kesimpulan sebagai berikut:

1. Berkaitan dengan strategi pengelolaan BUMD perseroan (perseroda) maka BUMD Aneka Usaha lebih cocok menggunakan konsep perusahaan pengendali atau membentuk perusahaan kelompok/grup (holding company) dengan group usaha horizontal, karena bergerak di berbagai bidang aneka usaha yang tidak berkaitan.

2. Hasil analisis kelayakan ekonomi menunjukan bahwa pendirian BUMD Aneka Usaha dengan layak untuk direalisasikan. Dari hasil perhitungan kriteria investasi diperoleh sebagau berikut nilai NPV sebesar Rp49.771.120.663,85>0, IRR $32 \%>10 \%$, Net B/C Ratio $12,78>1$ dan PP 4 tahun $<5$ tahun. 


\section{B. Saran}

Perlunya dilakukan sinkronisasi dan harmonisasi produk hukum yang mengatur tentang pengelolaan BUMD Aneka Usaha. Sinkronisasi dan harmonisasi dilakukan dengan cara vertikal dan horizontal terkait produk hukum yang mengatur tentang BUMD dari tingkatan yang paling tinggi sampai tingkatan yang paling rendah. Sinkronisasi secara horizontal dilakukan dengan cara melakukan analisas seberapa jauh peraturan perundangundangan yang mengatur tentang BUMD Aneka Usaha mempunyai hubungan fungsional secara konsisten

\section{DAFTAR PUSTAKA}

Abdul Halim, 2005, Analisis Investasi, Salemba Empat, Jakarta.

Afandi, 2006,Analisis Studi Kelayakan Investasi Pengembangan Usaha Distribusi PT. Aneka Andalan Karya, Fakultas Ekonomi Universitas Gunadarma. Bandung.

Ahmad Subagyo, 2008, Studi Kelayakan Teori dan Aplikasi, Elex Media Komputindo, Jakarta.

Badan Pusat Statistik (2001). Kabupaten Samosir Dalam Angka dan Bruto Kabupaten/Kota menurut lapangan usaha. Provinsi Sumatera Utara.

Brigham, Eugene G dan Joel F. Houston, 2001, Manajemen Keuangan, Buku 2 Alih Bahasa: Dodo Suharto dan Herman Wibowo, Jakarta: Erlangga.

Fred.J Weston \& Thomas E. Copeland, 2007, Manajemen Keuangan, Jilid I Edisi Kedelapan Terjemahan Jaka Wasana dan Kirbranoka, Erlangga, Jakarta.

Horne, James C. Van dan John M. Wachowicz, Jr, 2000, Prinsip-Prinsip Manajemen Keuangan, Buku Satu, Jakarta: Salemba Empat.

Husein Umar, 2014, Studi Kelayakan Bisnis , Edisi 4, Gramedia Pustaka Utama, Jakarta.

Kasmir dan Jakfar, 2012, Studi Kelayakan Bisnis, Edisi 3 Kencana, Jakarta.

Martono dan Agus Harjito, 2002, Manajemen Keuangan, Edisi Pertama, Cetakan

Peraturan Pemerintah Nomor 58 Tahun 2005 tentang pengelolaan Keuangan dan Kinerja Instansi Pemerintah;

Suad Husnan dan Suwarsono, 2001, Studi Kelayakan Proyek, UPP AMP YKPN, Yogyakarta.

Suad Husnan, 2001, Manajemen Keuangan Teori dan Penerapan (Keputusan Jangka Pendek), , Edisi Keempat, BPFE UGM, Yogyakarta.

Undang - Undang Nomor 32 Tahun 2004 tentang Pemerintahan Daerah, sebagaimana telah diubah dengan Undang-Undang Nomor 8 Tahum 2005, dan Undang-Undang 23 Tahun 2014;

Undang - Undang Nomor 33 Tahun 2004 tentang Perimbangan Keuangan antara Pemerintah Pusat dan Pemerintah Daerah; 